\title{
Viability of Brazilwood seeds (Caesalpinia echinata Lam.) stored at room temperature in controlled atmospheres ${ }^{1}$
}

\begin{abstract}
Nestor Martini Neto², Claudio José Barbedo²*
ABSTRACT - Seed storage at room temperature is an important and low-cost tool for ex situ conservation. However, the high rates of seed deterioration could reduce the potential for storage in this condition. Therefore, the knowledge of the suitable water content for this type of storage plays a critical role. This study aimed to assess the time required to stabilize the relative humidity $(\mathrm{RH})$ in sealed flasks with saturated salt solutions, with or without the introduction of seeds of Caesalpinia echinata, as well as to assess the viability of these seeds stored in environments with different hygroscopic equilibrium. The results showed that 2 and about 12 days are needed to stabilize the RH, respectively, without or with the seeds. The amount of saturated salt solutions in this airtight environment influences both the speed to equilibrate the RH and the final values of the RH. Seeds of Caesalpinia echinata tolerate drying up to 5\% water content (wet basis); however, the viability of these seeds at room temperature is maintained for short periods even at low water content.
\end{abstract}

Index terms: storage, hygroscopic equilibrium, desiccation tolerance.

\section{Viabilidade de sementes de pau-brasil (Caesalpinia echinata Lam.) mantidas em temperatura ambiente com atmosferas controladas}

\begin{abstract}
RESUMO - O armazenamento de sementes em temperatura ambiente é uma importante ferramenta como estratégia de conservação ex situ. No entanto, as altas taxas de deterioração diminuem o potencial de armazenamento. Diante disso, a busca do teor de água ótimo para este tipo de armazenamento assume papel fundamental. Este trabalho teve por objetivo avaliar o período necessário para equilíbrio da umidade relativa do ar (UR) em frascos herméticos a partir da introdução de soluções salinas saturadas e de sementes de Caesalpinia echinata, bem como avaliar a capacidade de manutenção da viabilidade dessas sementes em ambientes com diferentes equilíbrios higroscópicos. Os resultados permitiram verificar que são necessários dois dias para equilíbrio da UR a partir da inclusão de soluções salinas saturadas em ambiente hermético sem a presença de sementes, e cerca de 12 dias com a presença das sementes; que a quantidade de soluções salinas presente no ambiente hermético influencia a velocidade de equilíbrio da UR e o equilíbrio ao final do período e as sementes de Caesalpinia echinata suportam secagem até teores de água de 5\% (base úmida), mas mesmo com baixo teor de água estas sementes conservam-se por curtos períodos quando em temperatura ambiente.
\end{abstract}

Termos para indexação: armazenamento, equilíbrio higroscópico, tolerância à dessecação.

\section{Introduction}

Ex situ conservation of germplasm not only aims to exploit the economic potential of plant material, but also the preservation of endangered species, especially those with shortages of natural remnants (Pilatti et al., 2011; Barbedo et al., 2013). Among the forms of conservation, seed storage is considered safe and economically viable because, depending on the species and environmental conditions, the seeds can maintain their viability for decades, centuries or even millennia (Marcos-Filho, 2005; Ellis and Hong, 2006;
Sallon et al., 2008; Barbedo et al., 2013). However, the lack of basic knowledge about the behavior of seeds in many forest species, mainly the ones native from Brazil, hampers the use of this conservation strategy (Pilatti et al., 2011). It is known that the conservation of Caesalpinia echinata Lam., Brazilwood, for example, requires sub-zero temperatures (Hellmann et al., 2006), but the factors that lead to loss the viability of these seeds in less than 60 days when stored at or close to the ambient temperature are not known (Barbedo et al., 2002). This is a species that, in addition to its historical importance to Brazil and being one of the most important

${ }^{1}$ Submitted on 10/31/2014. Accepted for publication on 04/08/2015.

${ }^{2}$ Instituto de Botânica, Núcleo de Pesquisa em Sementes, Caixa Postal, 68041, 04301012 - São Paulo, SP, Brasil.

*Corresponding author< claudio.barbedo@pesquisador.cnpq.br> 
flora currently at risk of extinction and of its economic and pharmacological potential (Pilatti et al., 2011; Lamarca and Barbedo, 2012; Cruz-Silva et al., 2013; Gomes et al., 2014), produces seeds of great scientific interest because they are tolerant to desiccation, but with low storage capacity.

The seeds keep a constant exchange of moisture with the environment and therefore the water has great influence on their physiology. One of the major goals in seed storage studies is to control the movement of water between the seed and the environment, especially due to its participation in the deterioration processes of the seeds. The amount and energy of water in the seed are intrinsically related to the deterioration speed, activating the respiratory metabolism when in high amounts, causing deleterious reactions during excessive drying (Marcos-Filho, 2005; Barbedo et al., 2013). Seeds release or absorb water from their surrounding air, depending on the difference in vapor pressure of water in the seed and air. When the water pressure of the seed surface equals the ambient air vapor pressure, the hygroscopic equilibrium is obtained (Marcos-Filho, 2005; Carvalho and Nakagawa, 2012). Such dynamics can in many cases be controlled. For example, saturated salt solutions produce constant water vapor pressure at constant temperature (Vertucci and Roos, 1990; Sun, 2002) and are used in research aimed at analyzing the relationship between relative humidity (RH), temperature and moisture content equilibrium of the seeds (Choudhury et al., 2011; Bazin et al., 2011).

This relationship is obtained from water sorption isotherms, an important tool in the study of water relations in seeds that help find the ideal water content for the storage of each type of seed (Vertucci and Roos, 1990; Sun, 2002). Studies of this kind are primarily intended for identification of the critical point of water, i.e., one which provides the maximum storage time at a given temperature as well as the effects of different drying methods, considering different drying temperatures and rates, on the preservation of physical and physiological seed quality (Ballesteros and Walters, 2007; Buttler et al., 2009; Zhang et al., 2010). However, there are few studies that examine the dynamic equilibrium of the air inside the airtight flasks during drying and the time required for the seed to achieve hygroscopic equilibrium. It is also necessary to know whether this equilibrium depends on the species, the seed water content and the amount of saturated salt solutions in sealed flasks.

Brazilwood seeds have an orthodox behavior and can maintain viability for up to 18 months when stored at $7{ }^{\circ} \mathrm{C}$ (Barbedo et al., 2002) and up to five years at $-18{ }^{\circ} \mathrm{C}$ (Mello et al., 2013), at water content of about $10 \%$ in both cases. However, studies are inconclusive with regard to the storage of these seeds at room temperature, hindering the use of this low-cost way of storage (Lamarca and Barbedo, 2012). Therefore, knowledge of the dynamics of water between $C$. echinata seeds and their storage environment at different controlled atmospheres is of critical importance for the development of appropriate conditions for storage and thus for the preservation of the species by ex situ conservation. This study aimed to assess the time required for the equilibrium of RH in airtight flasks after the introduction of both saturated salt solutions and Caesalpinia echinata seeds (Brazilwood), as well as to assess the ability to maintain the viability of these seeds in environments with different hygroscopic equilibriums.

\section{Material and Methods}

Obtaining plant material: the seeds were obtained after natural shedding (less than 24 hours of dispersion and without rain in the 24 hours prior to harvesting), from approximately 25 mother trees, at random, in a wood of about 100 trees at Reserva Biológica e Estação Experimental de Moji-Guaçú (Biological Reserve and Research Station), in the city of Mogi-Guaçú $\left(47^{\circ} 09^{\prime} \mathrm{W}, 22^{\circ} 15^{\prime} \mathrm{S}\right.$, altitude $610 \mathrm{~m}$ ) and the Santa Carolina farm, in the city of Jaú (48 $30^{\prime} \mathrm{W}, 22^{\circ} 11^{\prime} \mathrm{S}$, altitude $\left.646 \mathrm{~m}\right)$, both in the state of São Paulo, Brazil. After collection, the seeds were transported to Laboratório de Sementes do Instituto de Botânica (Seed Laboratory of the Botanical Institute) (2337' S, 46 32' W, altitude $798 \mathrm{~m}$ ), in the city of São Paulo, where they were processed by eliminating cracked seeds or the ones infested by insects, but maintaining the control of the origin. After this selection, the seeds were dried to approximately $10 \%$ water content - WC (wet basis), in an oven at $40{ }^{\circ} \mathrm{C}$ (Barbedo et al., 2002). They were then stored in a freezer at $-18{ }^{\circ} \mathrm{C}$ (Hellmann et al., 2006; Mello et al., 2013) until the beginning of the experiments, not exceeding seven days of the date of collection.

Physical and physiological determinations: WC was gravimetrically determined by the oven method at $103 \pm 2{ }^{\circ} \mathrm{C}$ for 17 hours (Brasil, 2009) and the results are shown as a percentage, on a wet basis. The water potential (WP) of the embryos and seed coats were obtained by the potentiometer WP4 (Decagon, Pullmann), that uses the chilled mirror dewpoint method (Decagon Devices, 2000).

Germination tests were carried out in germination chambers $\left(25 \pm 1{ }^{\circ} \mathrm{C}\right.$ and $90 \pm 5 \%$ ) in paper rolls, with assessments every three days up to 15 days (Mello and Barbedo, 2007). Seeds that issued primary root with at least $1 \mathrm{~cm}$ were used to calculate the percentage of germinated seeds; those resulting in the development of normal seedlings (Barbedo et al., 2002) were used to calculate the percentage of germination.

The physiological quality of the seeds was also analyzed 
by the tetrazolium test, according to the methodology described by Lamarca et al. (2009). The seeds were pre-conditioned for 2 hours in water at $25^{\circ} \mathrm{C}$, then the coats were removed and the embryos were incubated in tetrazolium solution at $0.05 \%$ for two hours at $35{ }^{\circ} \mathrm{C}$ in the absence of light. Subsequently, the embryos were washed in running water, assessed and classified according to categories soft pink color (healthy tissue), deep red (deteriorating) and natural color of the tissue (dead tissue). In addition, the estimates of frequency distribution of viable, damaged and dead tissues of the seeds from each treatment were calculated (Lamarca and Barbedo, 2012).

Obtaining isotherms of water sorption in saturated salt solutions and period for equilibrium: the salts used were potassium chloride $(\mathrm{KCl})$, sodium chloride $(\mathrm{NaCl})$, sodium nitrite $\left(\mathrm{NaNO}_{2}\right)$ and calcium bromide $\left(\mathrm{CaBr}_{2}\right)$. To obtain the solutions, the salts in flasks were added containing deionized water until formation of the precipitate, according to the methodology described by Vertucci and Roos (1990) and Sun (2002), which were placed in an airtight environment at $25 \pm 1{ }^{\circ} \mathrm{C}$. The $\mathrm{RH}$ values of the flasks were obtained using a Data Logger hygrometer with Weather Station model 30.3015 (Incoterm, Porto Alegre), programed to record data every five minutes. This equipment is based on the measurement of RH and temperature, using different peripheral bases remaining in the flasks and communicating with the central base by radio waves, enabling such measurement without opening the flask (Incoterm, 2004).

For each salt, four target ratios between salt solution volume and air flask volume (hereinafter named SVAV) were established: 1:128 (or $7.8 \cdot 10^{-3} \mathrm{~mL}$ of solution . $\mathrm{mL}$ of air $^{-1}$, hereinafter $\mathrm{mL} \cdot \mathrm{mL}^{-1}$ ), 1:64 (or 1.6. 10-2 $\left.\mathrm{mL} . \mathrm{mL}^{-1}\right), 1: 32\left(3.1 .10^{-2} \mathrm{~mL} \cdot \mathrm{mL}^{-1}\right.$ ) and $1: 16\left(6.2 \cdot 10^{-2} \mathrm{~mL} \cdot \mathrm{mL}^{-1}\right)$. The air flask volume $(1,280 \mathrm{~mL})$ was calculated from the total volume of the airtight flask, by subtracting the volume occupied by the saturated salt solution and by the peripheral base of the hygrometer. To obtain those relationships were used, respectively, 9.90; 19.66; 38.73 and $75.18 \mathrm{~mL}$ of solution.

The RH values obtained by the hygrometer were converted to WP from the formula $\Psi=-\left[(\ln \mathrm{RH} / 100) \cdot\right.$ R.T. $\left.\overline{\mathrm{V}}_{\mathrm{a}}^{-1}\right]$ (Taiz and Zeiger, 2004), where $\Psi$ is the air WP (in MPa), $R$ is the gas constant, $\mathrm{T}$ is the temperature (in Kelvin) and $\overline{\mathrm{V}}_{\mathrm{a}}$ is the molar volume of water.

Before the beginning of the records of $\mathrm{RH}$, the airtight flasks remained for a week with $100 \mathrm{~g}$ of silica gel in beads in order to reduce the $\mathrm{RH}$ to values of approximately $5 \%$. After this period, the silica gel was removed and immediately replaced by the saturated salt solutions. The solutions remained in the airtight flask until the hygroscopic equilibrium was reached, i.e., when variations larger than $5 \%$ in $\mathrm{RH}$ of the flask were not registered for four hours.
Periods for hygroscopic equilibrium of the air of the flasks with saturated salt solutions in the presence of seeds: in order to verify changes in the periods necessary to achieve the hygroscopic equilibrium within the flasks when adding seeds, unviable (i.e., stored for more than two years in a natural environment and with zero germination) seeds of $C$. echinata of Mogi-Guaçu were used to prevent any metabolic activity that might interfere with the stability of RH, which would hinder its hygroscopic equilibrium with the salt solutions. Saturated salt solutions in the ratios described above were inserted into airtight flasks and remained for 48 hours, and then 50 seeds were placed (totaling $11.0 \pm 0.8 \mathrm{~g}$ ). In order to standardize and homogenize the water content, the seeds were stored for seven days in an airtight flask with deionized water in the bottom without contact with the seeds, which guaranteed RH of $95 \pm 5 \%$. The seeds were then placed in the sealed flasks and remained in these until the new equilibrium of moisture content was achieved, considered when a variation greater than $5 \%$ in $\mathrm{RH}$ of the flask was not recorded, over a four hour interval. After this period, the seeds were taken and characterized for WC and WP, as described above.

Seed storage in flasks with saturated salt solutions: seeds of C. echinata of Jaú, initially with $10 \% \mathrm{WC}$, were incubated for 15 days at $25^{\circ} \mathrm{C}$ and 12 hours of photoperiod in flasks with saturated salt solutions of zinc nitrate $\left(\mathrm{Zn}\left(\mathrm{NO}_{3}\right)_{2}\right)$, chloride calcium $\left(\mathrm{CaCl}_{2}\right)$, calcium bromide $\left(\mathrm{CaBr}_{2}\right)$ and zinc chloride $\left(\mathrm{ZnCl}_{2}\right)$, besides blue silica gel in beads previously dried in an oven. Different saturated salt solutions from those used in previous hygroscopic equilibrium experiments were selected, because the objective was to achieve lower WP, needed for the storage of seeds. The assembly of the flasks and salt solutions was performed as described above. At the end of 15 days, samples of the seeds were taken for analysis of WC, WP and germination, as described above. The remaining seeds were transferred to new flasks with the same saturated salt solutions described above and after 30 and 60 days (totaling 45 and 75 days of storage, respectively) they were again assayed for WP, $\mathrm{WC}$ and germination.

Experimental design: the experimental design for all experiments was completely randomized. The experiments of periods for equilibrium of $\mathrm{RH}$ were carried out in two replications and the ones involving seeds were in four replications. The experiment with seed storage in salt solutions was in a $5 \times 3$ factorial arrangement (storage environment versus storage period). The data obtained for WC and WP (these being always considered in module), germinated seeds and germination were submitted to analysis of variance (F test) at $5 \%$ probability. Means were compared by Tukey test at 5\% (Santana and Ranal, 2004). 


\section{Results and Discussion}

Obtaining isotherms of water sorption in saturated salt solutions and period needed for equilibrium:

Changes in RH of the flasks, i.e., less than $5 \%$, were very small for all salts after approximately 12 to 16 hours (Figure 1).
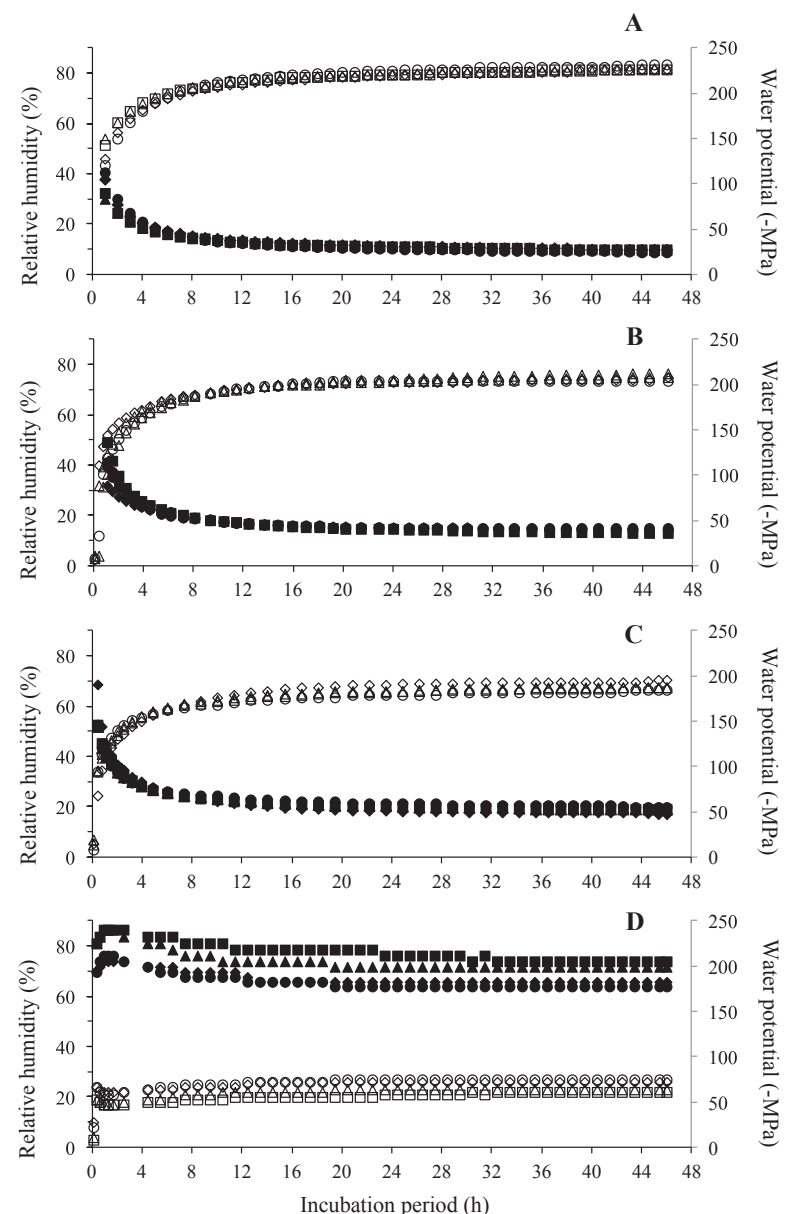

Figure 1. Relative humidity (open symbols) and water potential (filled symbols) of the sealed air chambers, empty, at $25{ }^{\circ} \mathrm{C}$ in salt solutions containing $\mathrm{KCl}$ (A), $\mathrm{NaCl}$ (B), $\mathrm{NaNO}_{2}$ (C) and $\mathrm{CaBr}_{2}$ (D) in the ratios of $7.8 .10^{-3}(\diamond) ; 1.6 .10^{-2}(\square) ; 3.1 .10^{-2}(\Delta)$ and $6.2 .10^{-2}(\mathrm{o})$, over 48 hours of incubation.

The hygroscopic equilibrium was achieved when the $\mathrm{RH}$ was about $82 \%$ for $\mathrm{KCl}$ (Figure 1A), $75 \%$ for $\mathrm{NaCl}$ (Figure 1B), $68 \%$ for $\mathrm{NaNO}_{2}$ (Figure 1C), and $25 \%$ for $\mathrm{CaBr}_{2}$ (Figure 1D). The first two values are within the range described by Sun (2002) for $25{ }^{\circ} \mathrm{C}$, namely respectively $84 \pm 2 \%$ and $75 \pm 2 \%$ and the value of $\mathrm{NaNO}_{2}$ was very close to that described by the author $(64 \pm 2 \%)$. However, the value recorded for $\mathrm{CaBr}_{2}$ was above the one described by that author $(16 \pm 2 \%)$. WP, in turn, ranged from approximately -200 $\mathrm{MPa}$ in $\mathrm{CaBr}_{2}$ to $-25 \mathrm{MPa}$ in $\mathrm{KCl}$ (Figure 1). Analyzing the RH, no differences were observed in the periods to achieve the moisture content equilibrium due to the variation of SVAV. However, when WP was analyzed, there was a slight variation in this period just for the $\mathrm{CaBr}_{2}$ solution (Figure 1D).

The seeds of $C$. echinata, when introduced into the flasks, contained approximately $32 \% \mathrm{WC}$, corresponding to approximately -15 $\mathrm{MPa}$. Immediately after the introduction of these seeds there was an increase in $\mathrm{RH}$ values, indicating that water was easily moved from the seeds to the air of the flasks with salt solutions (Figure 2). This resulted in reduction in WC of the seeds, which was the greater as was lower the initial RH of the flasks, reaching $6.3 \%(<-100 \mathrm{MPa})$ in the flasks with $\mathrm{CaBr}_{2}$ with a SVAV ratio of $6 \cdot 2 \cdot 10^{-2} \mathrm{~mL} \cdot \mathrm{mL}^{-1}$ (Table 1).

$\mathbf{A}$
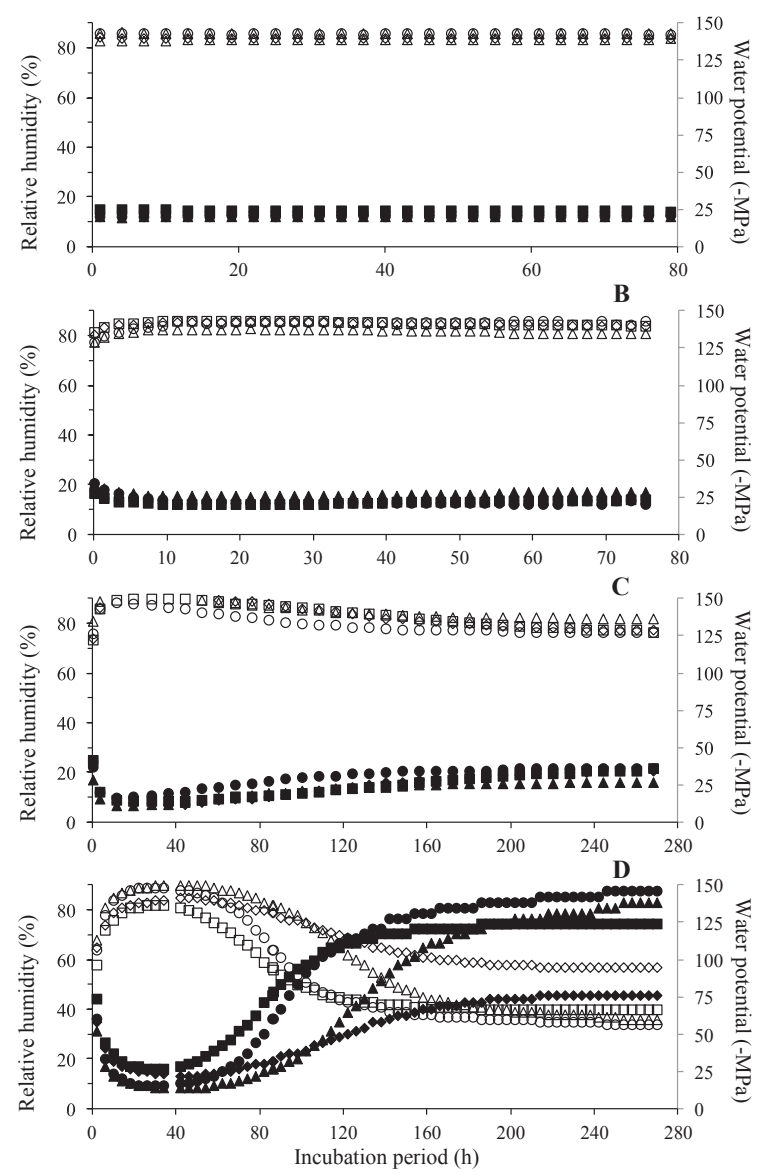

Figure 2. Relative humidity (open symbols) and water potential (filled symbols) of the airtight air chambers at $25{ }^{\circ} \mathrm{C}$ containing salt solutions of $\mathrm{KCl}(\mathrm{A}), \mathrm{NaCl}$ (B), $\mathrm{NaNO}_{2}$ (C) and $\mathrm{CaBr}_{2}$ (D) at the ratios of 7.8.10 ${ }^{3}(\diamond) ; 1.6 .10^{-2}(\square) ; 3.1 .10^{-2}(\Delta)$ and $6.2 .10^{-2}(o)$, over 48 hours of incubation after addition of 50 seeds of Caesalpinia echinata with $32 \%$ of water (-15 MPa). 
Table 1. Seed water content and water potential (-MPa) of embryo and seed coat of Caesalpinia echinata Lam. seeds after moisture equilibrium in an atmosphere controlled by saturated salt solutions.

\begin{tabular}{lccc}
\hline \multirow{2}{*}{ Salt solution } & Final water content $(\%)$ & Water potential (MPa) \\
\cline { 3 - 4 } $\mathrm{KCl}$ & $16.5 \mathrm{a}^{*}$ & $-27.6 \mathrm{a}$ & Embryo \\
$\mathrm{NaCl}$ & $12.7 \mathrm{~b}$ & $-44.5 \mathrm{a}$ & $-34.3 \mathrm{a}$ \\
$\mathrm{NaNO}_{2}$ & $10.7 \mathrm{c}$ & $-67.5 \mathrm{~b}$ & $-50.0 \mathrm{a}$ \\
$\mathrm{CaBr}_{2} 7.8 \cdot 10^{-3}$ & $7.5 \mathrm{~d}$ & $-91.5 \mathrm{c}$ & $-75.0 \mathrm{~b}$ \\
$\mathrm{CaBr}_{2} 1.6 \cdot 10^{-2}$ & $6.5 \mathrm{e}$ & $-116.8 \mathrm{~d}$ & $-97.3 \mathrm{c}$ \\
$\mathrm{CaBr}_{2} 3.1 \cdot 10^{-2}$ & $6.3 \mathrm{e}$ & $-128.3 \mathrm{~d}$ & $-131.7 \mathrm{~d}$ \\
$\mathrm{CaBr}_{2} 6.2 \cdot 10^{-2}$ & $6.5 \mathrm{e}$ & $-112.1 \mathrm{~d}$ & $-136.5 \mathrm{~d}$ \\
\hline
\end{tabular}

* Means followed by the same letter in columns do not differ by Tukey test at $5 \%$.

In the flasks with $\mathrm{KCl}$ solution, in which $\mathrm{RH}$ was already high $(82 \%$, Figure $1 \mathrm{~A})$, the introduction of the seeds practically did not change these values, rising about $4 \%$ and stabilizing at $84-85 \%$ at the end, or 270 minutes after the start of the experiment (Figure 2A), although the WC of the seeds has dropped by half (Table 1). In the flasks with $\mathrm{NaCl}$ solution, with RH $75 \%$ (Figure 1B), this one rose to $86 \%$ within the first 10 hours, and from this point on it showed a slight reduction, stabilizing at around $84 \%$, i.e., not returning to the initial $\mathrm{RH}$ (75\%, Figure 1B) even after over 70 hours of incubation (Figure 2B). The RH of the flasks with $\mathrm{NaNO}_{2}$ solution, initially at $68 \%$, increased to $92 \%$ in the first 15 hours following the addition of the seeds and then had a progressive reduction but, like in the flasks with the $\mathrm{NaCl}$, it did not return to the initial values, even after over 260 hours, stabilizing at about $80 \%$ (Figure 2C).

In the flasks with $\mathrm{CaBr}_{2}$ solution the greatest changes were observed. Initially with $\mathrm{RH}$ of $25 \%$, after adding seeds, the RH was increased to around $80 \%$ in the first 36 hours. From this point on, the RH progressively decreased but, similar to what occurred in the flasks with the other solutions, it also did not reach the initial values, even after 270 hours (Figure 2D). However, unlike what was observed in the other flasks, the ones containing $\mathrm{CaBr}_{2}$ solution had different $\mathrm{RH}$ stabilization values, depending on the SVAV relationship, and the less concentrated ones stabilized at higher RH. In SVAV of $7.8 .10^{-3} \mathrm{~mL} \cdot \mathrm{mL}^{-1}$, e.g., stabilization occurred at $57 \% \mathrm{RH}$, while in SVAV of $6.2 .10^{-2} \mathrm{~mL} \cdot \mathrm{mL}^{-1}$, RH stabilized at $34 \%$. These differences followed the same pattern of differences observed in the final values of $\mathrm{WC}$ of the seeds between the lower SVAV ratio $\left(7.8 \cdot 10^{-3} \mathrm{~mL} \cdot \mathrm{mL}^{-1}\right)$ and the others, as well as in the WP of embryos and coats (Table 1).

The changes in $\mathrm{RH}$ with the addition of seeds were accompanied by changes in WP of the air. The smaller the difference between the WP of the air in the flasks and of the seeds added to these flasks, the less variation in both WP and RH (Figure 2). Thus, in the flasks with $\mathrm{KCl}$ solution, in which the difference between these potentials was only $10 \mathrm{MPa}(-15 \mathrm{MPa}$ of the seeds, $-25 \mathrm{MPa}$ in the air of the flasks), there was practically no change in $\mathrm{RH}$; in those ones containing $\mathrm{NaCl}$, the difference was $25 \mathrm{MPa}(-40 \mathrm{MPa}$ in the flasks), which promoted an increase of $20 \mathrm{MPa}$ in the air (reaching -20 MPa); in the ones containing $\mathrm{NaNO}_{2}$, with a difference of $40 \mathrm{MPa}(-55$ $\mathrm{MPa}$ in the flasks), the increase was $40 \mathrm{MPa}$ (reaching -15 $\mathrm{MPa}$ ); and in the ones containing $\mathrm{CaBr}_{2}$, the increase was about ten-fold, reaching values between -15 and -30 MPa, depending on the SVAV relationship.

Sorption isotherms have been used for the analysis of seed water relations subjected to environments with saturated salt solutions and, in this situation, moisture content equilibrium is often defined from gravimetric assessments (Vertucci and Roos, 1990; Ballesteros and Walters, 2007; Gazor, 2010). However, usually, the sample is removed from the airtight flask for weighing, allowing gas exchanges between the air present in the airtight flask and the external atmosphere. The internal $\mathrm{RH}$, previously kept in equilibrium by means of saturated salt solutions, undergoes changes and goes back into the equilibrium process after closing the chamber. In this study it was clearly shown the importance of knowing the difference between the mass of the water content of seeds to be stored (or to be subjected to drying by the use of saturated salt solutions) and the initial and/or desired $\mathrm{RH}$ of the storage container, as well as the difference between their WP. A small amount of seeds (10 g in 1 liter of air) caused substantial changes in the moisture content equilibrium of the system.

\section{Seed storage in flasks with saturated salt solutions}

When comparing the literature information (Sun, 2002) regarding $\mathrm{RH}$ of equilibrium of the saturated salt solutions used with the RH values recorded in the flasks in which the 
seeds were stored, it appears that there was a slight increase during the 15 days of drying, probably due to the release of water from the seeds to the environment. In the flasks with $\mathrm{Zn}\left(\mathrm{NO}_{3}\right)_{2}$, for example, $\mathrm{RH}$ increased from $35 \%$ to $50 \%$; with $\mathrm{CaCl}_{2}$, from $29 \%$ to $35 \%$; with $\mathrm{CaBr}_{2}$, from $16 \%$ to $25 \%$. Only with $\mathrm{ZnCl}_{2}$, solution, $\mathrm{RH}$ hardly changed, remaining at around $5 \%$. The RH of the flasks with silica gel beads approached zero, preventing a better measure by the hygrometer.

There was no significant interaction for the water content of the seeds between the different flasks and storage periods (Table 2). This content showed slight increase from 15 to 45 days, but did not increase thereafter. Among the different flasks with salt solution, as expected, the seed water content was lower for the lower $\mathrm{RH}$, reaching values of less than $6 \%$ in silica and in
$\mathrm{ZnCl}_{2}$. However, even in these concentrations the germination was greater than $30 \%$ (Table 3), confirming the desiccation tolerance in seeds of $C$. echinata (Barbedo et al., 2002). Also confirmed was the low storage capacity of the seeds of this species in a nonrefrigerated environment (Mello et al., 2013) because even with very low WC there was reduction in the germination and in the values of germinated seeds; the longer the period of storage, the lower the germinability (Table 3 ). After 75 days of storage almost all seeds lost the ability to produce normal seedlings and start the growth of the primary root. Importantly, the sharpest losses in the germination of seeds of $C$. echinata occurred in the flasks with $\mathrm{Zn}\left(\mathrm{NO}_{3}\right)_{2}$, i.e., the wettest. Therefore, even when keeping for a short time at non-chilled temperatures, the need to keep these seeds with water content below $10 \%$ was evident.

Table 2. Water content of Caesalpinia echinata Lam. seeds incubated in airtight flasks with saturated salt solutions, stored for 45 and 75 days.

\begin{tabular}{lcccccc}
\hline \multirow{2}{*}{ Period of storage } & \multicolumn{5}{c}{ Salt solutions } & \multirow{2}{*}{ Average } \\
\cline { 2 - 6 } & $\mathrm{Zn}\left(\mathrm{NO}_{3}\right)_{2}$ & $\mathrm{CaCl}_{2}$ & $\mathrm{CaBr}_{2}$ & Silica gel & $\mathrm{ZnCl}_{2}$ & \\
\hline 0 days (initial) & 9.95 & 6.98 & 6.19 & 5.62 & 4.78 & $6.70 \mathrm{~b}^{*}$ \\
45 days & 11.84 & 7.42 & 6.75 & 5.77 & 5.06 & $7.37 \mathrm{a}$ \\
75 days & 12.40 & 7.26 & 6.50 & 5.51 & 6.08 & $7.55 \mathrm{a}$ \\
Average & $11.40 \mathrm{~A}$ & $7.22 \mathrm{~B}$ & $6.48 \mathrm{BC}$ & $5.63 \mathrm{CD}$ & $5.30 \mathrm{D}$ & \\
\hline
\end{tabular}

*Means followed by the same letter (lowercase in columns, uppercase in rows) do not differ by Tukey test at $5 \%$.

Table 3. Germination and germinated seeds (\%) of Caesalpinia echinata stored for 15,45 or 75 days at $25{ }^{\circ} \mathrm{C}$ in airtight flasks containing silica gel or saturated salt solutions.

\begin{tabular}{|c|c|c|c|c|c|c|}
\hline \multirow{3}{*}{ Content in the flasks } & \multicolumn{6}{|c|}{ Storage periods } \\
\hline & \multicolumn{3}{|c|}{ Germinated seeds } & \multicolumn{3}{|c|}{ Germination } \\
\hline & 15 days & 45 days & 75 days & 15 days & 45 days & 75 days \\
\hline (initial values) & \multicolumn{3}{|c|}{ (90) } & \multicolumn{3}{|c|}{$(50)$} \\
\hline $\mathrm{Zn}\left(\mathrm{NO}_{3}\right)_{2}$ & $65 \mathrm{aA}^{*}$ & $22 \mathrm{bB}$ & $0 \mathrm{aC}$ & $17 \mathrm{bA}$ & $0 \mathrm{aB}$ & $0 \mathrm{aB}$ \\
\hline $\mathrm{CaCl}_{2}$ & $50 \mathrm{abA}$ & $55 \mathrm{aA}$ & $8 \mathrm{aB}$ & $35 \mathrm{aA}$ & $0 \mathrm{aB}$ & $3 \mathrm{aB}$ \\
\hline $\mathrm{CaBr}_{2}$ & $30 \mathrm{cAB}$ & $45 \mathrm{abA}$ & $15 \mathrm{aB}$ & $8 \mathrm{cA}$ & $0 \mathrm{aA}$ & $0 \mathrm{aA}$ \\
\hline Silica gel & $41 \mathrm{bcA}$ & $38 \mathrm{abA}$ & $5 \mathrm{aB}$ & $30 \mathrm{aA}$ & $2 \mathrm{aB}$ & $0 \mathrm{aB}$ \\
\hline $\mathrm{ZnCl}_{2}$ & $45 \mathrm{abcA}$ & $50 \mathrm{aA}$ & $20 \mathrm{aB}$ & $25 \mathrm{aA}$ & $0 \mathrm{aB}$ & $0 \mathrm{aB}$ \\
\hline
\end{tabular}

*Means followed by the same letter (lowercase comparing storage periods, uppercase letters comparing storage environment) do not differ by Tukey test at $5 \%$.

Analyzing the results obtained from the distribution of frequencies among viable, damaged and dead tissues, identified by the tetrazolium test, it was found that the ratios do not change much, both among the drying treatments and among the storage periods (Figure 3). This fact had already been pointed out by Lamarca and Barbedo (2012), who observed that it is possible that some non-viable seeds of $C$. echinata still show a large amount of viable tissues. However, the tetrazolium test identified the most severely affected tissues, both during storage and during drying. It was observed that the seeds with the highest WC (in a solution of $\left.\mathrm{Zn}\left(\mathrm{NO}_{3}\right)_{2}\right)$ showed, after the drying period, damage in the area of the root-hypocotyl axis, but still had viable tissues in the insertion areas of the cotyledons to the axis and in the proximal and distal areas of the cotyledon. After the first 45 days of storage, the seeds already exhibited the large majority of tissues in a deteriorating state (Figure 4D) and after 75 days damage throughout the root hypocotyl area, besides the area of axis insertion to the cotyledon, plumule and the proximal area of the cotyledon (Figure $4 \mathrm{H}$ ). The seeds subjected to 
the most severe drying $\left(\mathrm{CaCl}_{2}, \mathrm{CaBr}_{2}\right.$ and $\left.\mathrm{ZnCl}_{2}\right)$ showed slower deterioration of the tissues and it was possible to see damage primarily in the areas of the procambium, proceeding toward the fundamental meristem, the area of insertion of the cotyledons to the axis, plumule, and proximal and distal areas (Figures 4I-L). The damage done to both the meristem and the plumule has not always prevented seed germination; however, it is probably responsible for the production of abnormal seedlings (Figures 4 O-P). After 75 days of storage, however, the damage could be seen throughout the insertion area of the cotyledon to the axis, and, in this case, the association with the lower germination percentage was possible (Figures $4 \mathrm{H}$ and L and Table 3).

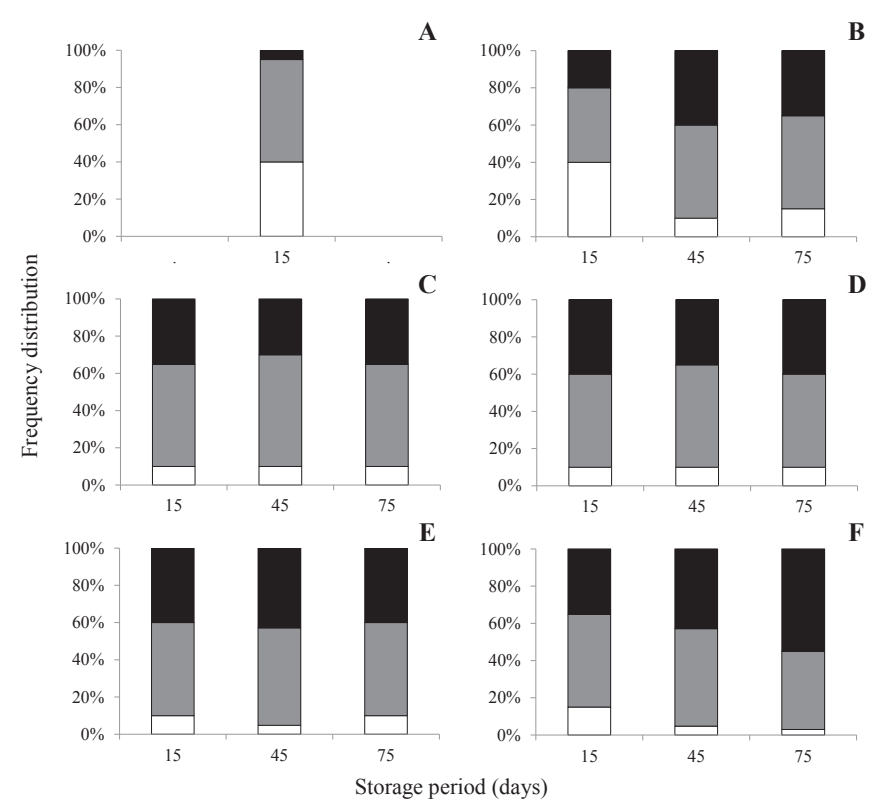

Figure 3. Frequency distribution of viable (white), deteriorated (gray) and dead (black) tissued obtained in the tetrazolium test of seeds of Caesalpinia echinata Lam. in control (A) or stored for 15,45 and 75 days in a sealed environment in a controlled atmosphere by saturated salt solutions of $\mathrm{Zn}\left(\mathrm{NO}_{3}\right)_{2}(\mathrm{~B}), \mathrm{CaCl}_{2}(\mathrm{C}), \mathrm{CaBr}_{2}(\mathrm{D})$, by silica gel beads $(\mathrm{E})$ and $\mathrm{ZnCl}_{2}(\mathrm{~F})$.

Thus, the results regarding tolerance to desiccation of seeds of $C$. echinata corroborate the results obtained by Hellmann et al. (2006) when storing the seeds of C. echinata with approximately $10 \%$ moisture content (wet basis) and suggesting that the water contents of less than this, such as from $3 \%$ to $7 \%$, typically used in gene banks, could further increase the longevity of seeds at a temperature of $-18{ }^{\circ} \mathrm{C}$. Finally, seeds of $C$. echinata still have a low period of longevity at room temperature. However, the drying does not appear to be responsible for the deleterious effects on $C$. echinata seeds.

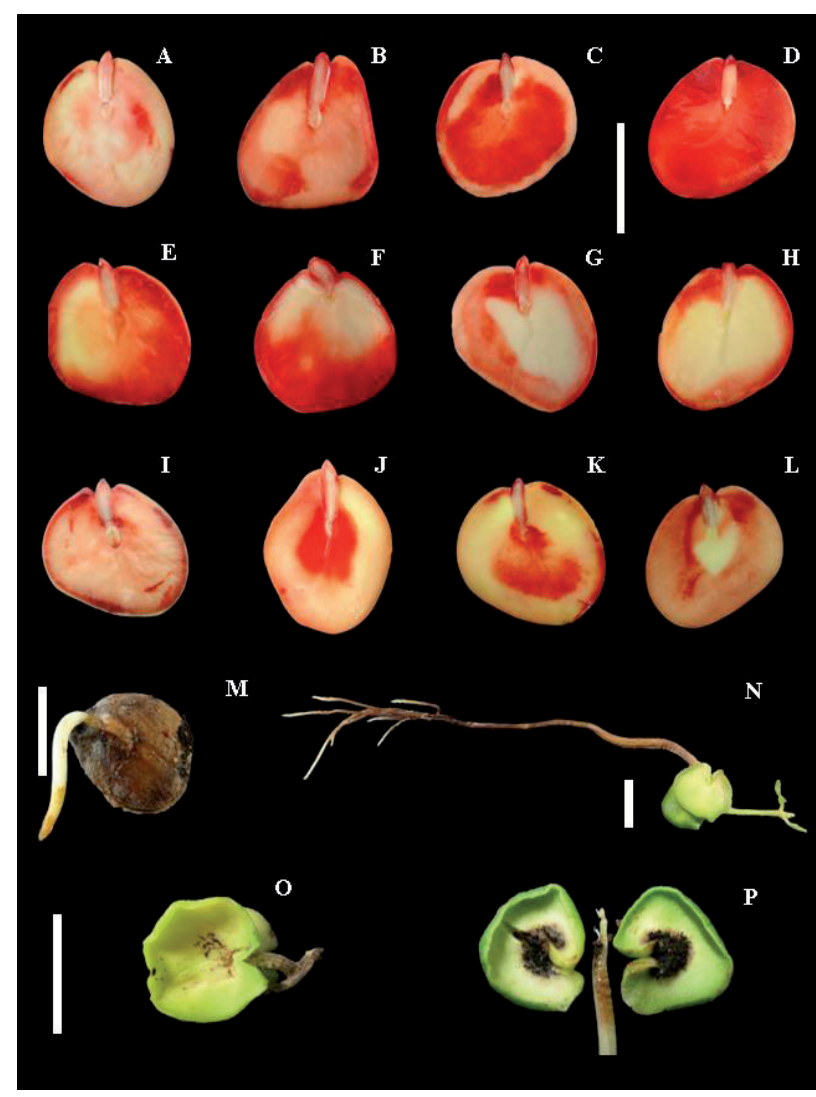

Figure 4. Classes of seeds of C. echinata in the tetrazolium test (A to L) and types of development in the germination test ( $\mathrm{M}$ to $\mathrm{P})$. $\mathrm{A}$ : viable and vigorous seed; B: seed with tissue deterioration in the distal area of the cotyledon; $\mathrm{C}$ : seed with deteriorating tissues throughout the proximal area of the cotyledon; D: seed with deteriorating tissues in all the cotyledon and dead tissues in the insertion area of the cotyledons to the axis; E and F: seeds with dead tissues in the proximal area of the cotyledon; $\mathrm{G}$ and $\mathrm{H}$ : seeds with dead tissues throughout the proximal area of the cotyledon; I: seed with dead tissues in the insertion area of the axis to the cotyledon; J and $\mathrm{K}$ : seeds with dead tissues in the distal area of the cotyledon; L: seed with dead tissues in the proximal area of the cotyledon; $\mathrm{M}$ : seed with primary root protrusion; $\mathrm{N}$ : normal seedling development; $\mathrm{O}$ and $\mathrm{P}$ : development of abnormal seedlings. Scale of $1 \mathrm{~cm}$. 


\section{Conclusions}

It takes 48 hours for equilibrium of the relative humidity from the inclusion of saturated salt solutions in an airtight environment without the presence of seeds, and about 12 days in the presence of seeds. The amount of salt solutions present in an airtight environment influences not only the relative humidity of the equilibrium velocity as well as the equilibrium at the end of this period.

Caesalpinia echinata seeds tolerate drying up to a water content of 5\% (wet basis), but even with low water content, in the salt solutions that most seeds remained viable $\left(\mathrm{CaCl}_{2}\right.$ and $\mathrm{ZnCl}_{2}$ ), these seeds maintain viability for short periods when at room temperature.

\section{Acknowledgments}

To the workers at Reserva Ecológica and Estação Experimental de Mogi Guaçu and Fazenda Santa Carolina for their assistance in the collection of Brazilwood fruits and seeds; to Instituto de Botânica and Fazenda Santa Carolina for permission to these collections; to Conselho Nacional de Desenvolvimento Científico e Tecnológico (CNPq; National Counsel of Technological and Scientific Development) for granting scholarships for master's degree (N. Martini Neto) and research productivity (C.J. Barbedo).

\section{References}

BALLESTEROS, D.; WALTERS, C. Water properties in fern spores: sorption characteristics relating to water affinity, glassy states, and storage stability. Journal of Experimental Botany, v.58, p.1185-1196, 2007. http:// jxb.oxfordjournals.org/content/58/5/1185.full.pdf $+\mathrm{html}$

BARBEDO, C.J.; BILIA， D.A.C.; FIGUEIREDO-RIBEIRO, R.C.L. Tolerância à dessecação e armazenamento de sementes de Caesalpinia echinata Lam. (pau-brasil), espécie da Mata Atlântica. Revista Brasileira de Botânica, v.25, p.431-439, 2002. http://www.scielo.br/pdf/rbb/v25n4/ a07v25n4.pdf

BARBEDO, C.J.; CENTENO, D.C.; FIGUEIREDO-RIBEIRO, R.C.L. Do recalcitrant seeds really exist? Hoehnea, v.40, p.583-593, 2013. http://www. scielo.br/pdf/hoehnea/v40n4/01.pdf

BAZIN, J.; BATLLA, D.; DUSSERT, S.; MAAROUF-BOUTEAU, H.; BAILLY, C. Role of relative humidity, temperature, and water status in dormancy alleviation of sunflower seeds during dry after-ripening. Journal of Experimental Botany, v.62, p.627-640, 2011. http://jxb.oxfordjournals.org/ content/62/2/627.full.pdf + html

BRASIL. Ministério da Agricultura, Pecuária e Abastecimento. Regras para análise de sementes. Ministério da Agricultura, Pecuária e Abastecimento. Secretaria de Defesa Agropecuária. Brasília: MAPA/ACS, 2009. 395p. http:// www.agricultura.gov.br/arq_editor/file/2946_regras_analise_sementes.pdf.
BUTTLER, L.H.; HAY, F.R.; ELLIS, R.H.; SMITH, R.D. Post abscission, predispersal seeds of Digitalis purpurea remain in a developmental state that is not terminated by dessication ex plant. Annals of Botany, v.103, p.785-794, 2009. http://aob.oxfordjournals.org/content/early/2009/01/09/aob.men254.full.pdf + html

CARVALHO, N.M.; NAKAGAWA, J. Sementes: ciência, tecnologia e produção. 5.ed. Jaboticabal: FUNEP, 2012. 588p.

CHOUDHURY, D.; SAHU, J.K.; SHARMA, G.D. Moisture sorption isotherms, heat of sorption and properties of sorbed water of raw bamboo (Dendrocalamus longispathus) shoots. Industrial Crops and Products, v.33, p.211-216, 2011. http://www.sciencedirect.com/science/article/pii/S0926669010002591

CRUZ-SILVA, I.; NEUHOF, C.; GOZZO, A.J.; NUNES, V.A.; HIRATA, I.Y.; SAMPAIO, M.U.; FIGUEIREDO-RIBEIRO, R.C.L.; NEUHOF, H.; ARAÚJO, M.S. Using a Caesalpinia echinata Lam. protease inhibitor as a tool for studying the roles of neutrophil elastase, cathepsin $\mathrm{G}$ and proteinase 3 in pulmonary edema. Phytochemistry, v.96, p.235-243, 2013. http://www. sciencedirect.com/science/article/pii/S0031942213003932\#

DECAGON DEVICES, I. Dewpoint PotentiaMeter - Operator's manual. Pullman: Decagon, 2000. 78p

ELLIS, R.H.; HONG, T.D. Temperature sensitivity of the low-moisturecontent limit to negative seed longevity-moisture content relationships in hermetic storage. Annals of Botany, v.97, p.785-791, 2006. http://aob. oxfordjournals.org/content/97/5/785.full.pdf + html

GAZOR, H.R. Moisture isotherms and heat of desorption of canola. Agricultural Engineering International: the CIGR Ejournal, v.12, manuscript 1440, 2010. http:// www.cigrjournal.org/index.php/Ejounral/article/view/1440/1296

GOMES, E.C.B.S.; JIMENEZ, G.C.; SILVA, L.C.N.; SÁ, F.B.; SOUZA, K.P.C.; PAIVA, G.S.; SOUZA, I.A. Evaluation of antioxidant and atiangiogenic properties of Caesalpinia echianata extracts. Journal of Cancer, v.5, p.143-150, 2014. http://www.jcancer.org/v05p0143.pdf

HELLMANN, M.E.; MELLO, J.I.O.; FIGUEIREDO-RIBEIRO, R.C.L.; BARBEDO, C.J. Tolerância ao congelamento de sementes de pau-brasil (Caesalpinia echinata Lam.) influenciada pelo teor de água. Revista Brasileira de Botânica, v.29, p.91-99, 2006. http://www.scielo.br/pdf/rbb/ v29n1/a09v29n1.pdf

INCOTERM. Estação meteorológica controlada por sinais de rádio mod. 30.3015. Manual de instruções. Porto Alegre: Incoterm, 2004. 24p.

LAMARCA, E.V.; BARBEDO, C.J. Short storability of Caesalpinia echinata Lam. seeds as a consequence of oxidative processes. Hoehnea, v.39, p.577-586, 2012. http://www.scielo.br/pdf/hoehnea/v39n4/06.pdf

LAMARCA, E.V.; LEDUC, S.N.M.; BARBEDO, C.J. Viabilidade e vigor de sementes de Caesalpinia echinata Lam. (pau-brasil - Leguminosae) pelo teste de tetrazólio. Revista Brasileira de Botânica, v.32, p.793-803, 2009. http://www.scielo.br/pdf/rbb/v32n4/a17v32n4.pdf

MARCOS-FILHO, J. Fisiologia de sementes de plantas cultivadas Piracicaba: FEALQ, 2005. 495p.

MELLO, J.I.O.; FIGUEIREDO-RIBEIRO, R.C.L.; BARBEDO, C.J. Sub-zero temperature enables storage of seeds of Caesalpinia echinata Lam. Journal of Seed Science, v.35, p.519-523, 2013. http://www.scielo.br/pdf/jss/v35n4/14.pdf

MELLO, J.I.O.; BARBEDO, C.J. Temperatura, luz e substrato para a germinação de sementes de pau-brasil Caesalpinia echinata Lam. Leguminosae-Caesalpinoidae. Revista Árvore, v.31, p.645-655, 2007. http:// www.scielo.br/pdf/rarv/v31n4/09.pdf 
PILATTI, F.K.; AGUIAR, T.; SIMÕES, T.; BENSON, E.E.; VIANA, A.M. In vitro and cryogenic preservation of plant biodiversity in Brazil. In Vitro Cellular and Developmental Biology - Plant, v.47, p.92-98, 2011. http://link. springer.com/article/10.1007\%2Fs11627-010-9302-y\#page-1

SALLON, S; SOLOEW, E.; COHEN, Y.; KORCHINSKY, R.; EGLI, M.; WOODHATCH, I.; SIMCHONI, O.; KISLEV, M. Germination, genetics, and growth of an ancient date seed. Science, v.320, p.1464, 2008. http://www. sciencemag.org/content/320/5882/1464.full.pdf

SANTANA, D.G.; RANAL, M.A. Análise da germinação: um enfoque estatístico. Universidade de Brasília: Brasília, 2004. 248p.

SUN, W.Q. Methods for the study of water relations under dessication stress. In: BLACK, M.; PRITCHARD, H.W. (Eds.) Dessication and survival in plants: drying without dying. Wallingford/New York: CABI Publishing, 2002. 84p.
TAIZ, L.; ZEIGER, E. Fisiologia vegetal. 3.ed. Porto Alegre: Artmed, 2004. 613p.

VERTUCCI, C.W.; ROOS, E.E. Theoretical basis of protocols for seed storage. Plant Physiology, v.94, p.1019-1023, 1990. http://www.plantphysiol. org/content/94/3/1019.full.pdf + html

ZHANG, M.; ZHUO, J.; WANG, X.; WU, S.; WANG, X. Optimizing seed water content: relevance to storage stability and molecular mobility. Journal of Integrative Plant Biology, v.52, p.324-331, 2010. http://www.jipb.net Abstract.aspx?id $=5666$ 